\title{
POST-HARVEST STORAGE OF PAPAYA FRUITS COATED WITH EXTRACTS OF LEAVES AND FRUITS OF NEEM ${ }^{1}$
}

\author{
RAIMUNDA VALDENICE DA SILVA FREITAS ${ }^{2}$, PAHLEVI AUGUSTO DE SOUZA ${ }^{2}$, ROSEMBERG FERREIRA \\ SENHOR $^{3}$, CARLOS FARLEY HERBSTER MOURA ${ }^{4}$, FRANCISCLEUDO BEZERRA DA COSTA ${ }^{5}$
}

\begin{abstract}
The objective of the present work was to evaluate the use of extracts of leaves and fruits of neem (Azadirachta indica Juss) as coating for papaya Formosa fruits aiming to maintain their quality during post-harvest storage. A completely randomized experimental design in a $5 \times 5$ factorial arrangement was used, with 3 replications of 2 papaya fruits per plot. The treatments consisted of five coatings with extracts of neem leaves and fruits (leaf extracts at 5 and $10 \%$, fruit extracts at 5 and $10 \%$ and a control treatment without coating) and five storage periods $\left(0,3,6,9\right.$ and 12 days) under mean temperature of $30.4{ }^{\circ} \mathrm{C}$ and relative humidity of $42 \%$. The fruit weight loss, external appearance, pulp firmness, titratable acidity and soluble solids were evaluated, and the fungi species on the fruit surface of each storage were identified and quantified. The treatments with extract of neem leaves and fruits at 5\% had papaya fruits with best external quality and provided best control of growth of phytopathogenic fungi. Regarding external appearance, papaya fruits coated with extracts of neem leaves and fruits at $5 \%$ had a shelf life of 12 days, while those coated with extracts at $10 \%$ had a shelf life of 9 days.
\end{abstract}

Palavras-chave: Azadirachta indica Juss. Coating. Quality. Fungi.

\section{ARMAZENAMENTO PÓS-COLHEITA DE FRUTOS DO MAMOEIRO RECOBERTOS COM EXTRATOS DAS FOLHAS E FRUTOS DO NIM}

\begin{abstract}
RESUMO - O presente trabalho teve como objetivo avaliar uso de extrato à base de folhas e de frutos do nim (Azadirachta indica Juss) como recobrimento na manutenção da qualidade pós-colheita do mamão Formosa. O delineamento utilizado foi o inteiramente casualizado em esquema fatorial $5 \mathrm{x} 5$, no qual o primeiro fator constou dos tipos de recobrimentos a base de folhas e frutos do nim (controle TC, extrato das folhas a 5\% - T1, extrato das folhas a $10 \%$ - T2, extrato dos frutos a $5 \%$ - T3 e extrato dos frutos a $10 \%$ - T4) e o segundo fator dos tempos de armazenamento (0, 3, 6, 9 e 12 dias) a temperatura média de $30,4{ }^{\circ} \mathrm{C}$ e UR de $42 \%$, com 3 repetições de 2 frutos por parcela. A cada tempo de armazenamento foram avaliadas perda de massa, aparência externa, firmeza da polpa, teor de acidez titulável, sólidos solúveis, percentual de fungos na superfície dos frutos e identificação de espécies de fungos. O extrato das folhas e dos frutos de nim a 5\% apresentaram os melhores resultados por manter a qualidade externa dos frutos, além de controlar o crescimento dos fungos fitopatogênicos. Com base na aparência externa, os frutos de mamão tratados com extratos das folhas e dos frutos do nim a 5\% tiveram vida útil de 12 dias. Os frutos recobertos com extratos das folhas e dos frutos a $10 \%$ apresentaram vida útil de 9 dias.
\end{abstract}

Palavras-chave: Azadirachta indica Juss. Revestimento. Qualidade. Fungos.

\footnotetext{
${ }^{*}$ Corresponding author

${ }^{1}$ Received for publication in $08 / 30 / 2016$; accepted in $05 / 24 / 2017$.

Paper extracted from masters dissertation of the first author.

${ }^{2}$ Department of Food Technology, Instituto Federal de Educação, Ciência e Tecnologia do Ceará, Limoeiro do Norte, CE, Brazil; valdenice2006@yahoo.com.br, pahlevi@ifce.edu.br.

${ }^{3}$ Production Manager, Agrícola Famosa, Mossoró, RN, Brazil; berg_fit@hotmail.com.

${ }^{4}$ Department of Agronomy (Plant Science), Empresa Brasileira de Pesquisa Agropecuária, Fortaleza, CE, Brazil; farley.moura@embrapa.br.

${ }_{5}^{5}$ Department Agricultural Sciences, Universidade Federal de Campina Grande, Pombal, PB, Brazil; franciscleudo@ccta.ufcg.edu.br.
} 


\section{INTRODUCTION}

Papaya is a climacteric fruit of high ethylene production and high to very high respiratory rate, whose characteristics promote organoleptic alterations during its maturation, and make this fruit very perishable (COSTA; BALBINO, 2002; PEREIRA et al., 2006; SOUZA et al., 2014).

One of the problems in the storage of papaya is the fruit rotting, which causes large post-harvest losses. According to Liberato and Tatagiba (2001), the fungi Colletotrichum gloeosporioides Penz. and Phoma caricae papaya are responsible for the major post-harvest papaya diseases, anthracnose and dry rot. The control of these diseases has been achieved through continuous chemical spraying programs, but the use of these products causes several undesirable consequences when used improperly. Thus, alternatives to control possible post-harvest diseases and meet the needs of producers and consumers have been studied, with emphasis on the use of extracts with antimicrobial activity, aiming to reduce the use of pesticides (BRITO et al., 2011; FERREIRA et al., 2014; NASCIMENTO; NERY; RODRIGUES, 2008).

The use of herbal plants is one of these alternatives, considering the great variability of existing species, low cost of these products, easy availability in rural properties and mainly, absence or low risks of contamination for the environment, animals and humans (AGNOLIN et al., 2010). Neem (Azadirachta indica Juss) is the most used plant of insecticidal action due to the contents of several substances with biological activity (azadirachtin, meliantriol, limonene, odoratone and other triterpenoids) in its leaves, bark, fruits and seeds; and its low cost, low polluting potential and low residual potential compared with synthetic products, thus presenting low risk of intoxication for mammals and birds (QUINTELA; PINHEIRO, 2004).

According to Wang et al. (2010), the growth of pathogens in plum and pear fruits can be reduced with the use of neem extracts. The fungicidal effect of neem was also observed in pineapple (RIBEIRO et al., 2011), tomato (LIMA et al., 2011; OLADIMEJI et al., 2013), apple (LEITE et al., 2009) and orange (AL-SAMARRAI; SINGH; SYARHABIL, 2013). However, studies on the use of extracts of leaves and fruits of neem in the control of post-harvest diseases in Papaya Formosa Tainung-01 are scarce. The use of alternative substances to control post-harvest papaya diseases may reduce the use of fungicides, providing greater protection to the consumer's health, helping to preserve the environment and maintaining fruit quality for a longer post-harvest period.

The objective of the present work was to evaluate the use of extracts of leaves and fruits of neem (Azadirachta indica Juss) as coating for papaya Formosa fruits aiming to maintain their quality during post-harvest storage.

\section{MATERIAL AND METHODS}

Fruits of the papaya Formosa Tainung-01 with first signs of skin yellowing (maturation stage 1) were manually collected from an orchard in Quixeré, State of Ceará (CE), Brazil. These fruits were packed in plastic containers and transported to the Pilot Fruit and Vegetable Processing Plant of the Federal Institute of Education, Science and Technology of Ceará, Campus Limoeiro do Norte, Brazil. They were then selected, sanitized with active chlorine solution (100 ppm) and divided into five groups: control $(\mathrm{TC}=$ uncoated $)$, coating with extracts of neem leaves $(\mathrm{T} 1=5 \%, \mathrm{~T} 2=10 \%)$ and coating with extracts of neem fruits (T3=5\%, T4=10\%).

Neem leaves with petioles were collected, distributed in trays and dehydrated in a forced-air circulation oven at $65^{\circ} \mathrm{C}$ for $48 \mathrm{~h}$. Subsequently, the dried leaves were ground to obtain the powder with a mill (Willye, Star FT 50).

Samples of 50 and $100 \mathrm{~g}$ of powdered leaves were diluted in $1 \mathrm{~L}$ of water to each concentration (5 and $10 \%$ ) to prepare the extracts used in the treatments $\mathrm{T} 1$ and $\mathrm{T} 2$. The resulting solutions were filtered with a cotton cloth to obtain only the aqueous extract, to which $1.5 \mathrm{~mL}$ of adhesive spreader (Activate ${ }^{\circledR}$ ) was added to improve its fixation on the papaya fruit surface.

Green and mature fruits of neem were harvested manually to elaborate the extracts used in the treatments T3 and T4. These fruits were sanitized with active chlorine solution (5 ppm) and ground in an industrial blender $\left(\mathrm{FAK}^{\circledR}\right)$ to obtain a dough, which was filtrated through a cotton cloth to obtain the aqueous extract. Aliquots of 50 and $100 \mathrm{~mL}$ of this extract were diluted in water with $1.5 \mathrm{~mL}$ of adhesive spreader.

The coating process consisted of immersing the fruits (for one minute) in the aqueous extract of leaves or neem fruits, according to the different concentrations. The control fruits (TC) were immersed for one minute in water containing only the adhesive spreader. Afterwards, all fruits were subjected to natural drying, stored in expanded polystyrene trays and stored at mean temperature of $30.4{ }^{\circ} \mathrm{C}$ and relative humidity of $42 \%$ for 12 days.

The fruit weight loss $(\%)$ of each storage period $(0,3,6,9$ and 12 days) were evaluated in a semi-analytical balance, considering the difference between the initial weight of the fruit. Fruit pulp firmness (N) was determined using a manual penetrometer (McCormick model FT 327) with an $8 \mathrm{~mm}$ diameter ferrule. Fruit external appearance was visually evaluated, using a subjective scale from 1 to 5 (LIMA et al., 2004), considering the absence or presence of defects, wilt and fungal attack symptoms. Soluble solids content ( ${ }^{\circ}$ Brix) was 
determined in the filtered juice using a digital refractometer. Titratable acidity (\% of malic acid) was evaluated by titration of $10 \mathrm{~mL}$ of the sample with $\mathrm{NaOH}$ solution $(0.1 \mathrm{~N})$ (IAL, 2008). Incidence of fungi $(\%)$ were determined by visual analysis, performed at each storage period, using the fungi percentage classification adopted by Azevedo (1998), with some adaptations. The identification of fungal species was performed considering the morphological characteristics of their reproductive structures, evaluated under an electronic microscope.

A completely randomized experimental design in a $5 \times 5$ factorial arrangement was used consisting of different types of coatings $(\mathrm{TC}=$ control, $\mathrm{T} 1=$ extract of the neem leaves at $5 \%$, $\mathrm{T} 2=$ extract of the neem leaves at $10 \%$, $\mathrm{T} 3=$ extract of neem fruits at $5 \%$ and $\mathrm{T} 4=$ extract of neem fruits at $10 \%)$ and storage period $(0,3,6,9$ and 12 days), with 3 replicates of 2 fruits per plot, totaling 150 fruits. The results were evaluated by comparing the means of the treatments followed by the standard deviation $(n=3)$.

\section{RESULTS AND DISCUSSION}

There was a gradual increase in the means of weight loss over the storage period, especially for TC fruits (Figure 1A). Fruits in T1 and T3 had the highest weight loss on the $12^{\text {th }}$ day, with 16.32 and $17.64 \%$, respectively. Fruits in T4 had a lower weight loss, reaching $9.94 \%$ at the end of the storage period. According to Chitarra and Chitarra (2005), $10 \%$ is the maximum acceptable weight loss for

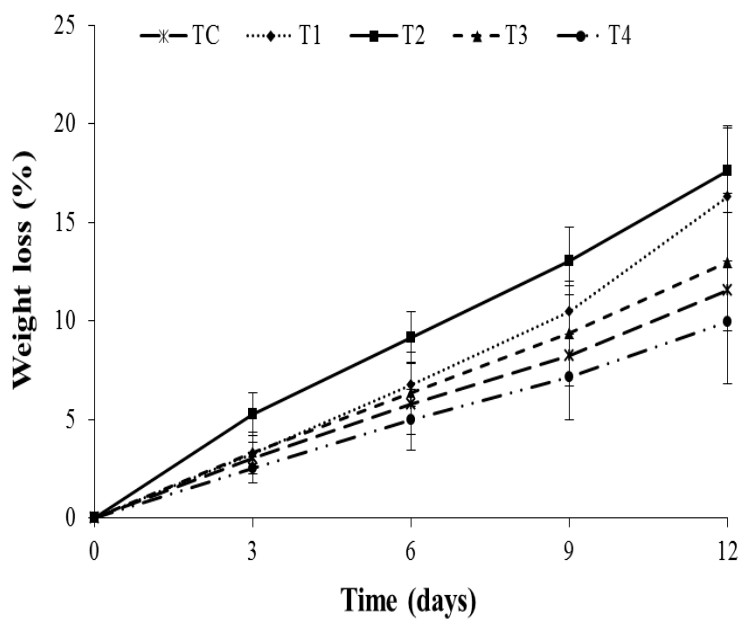

fruits and vegetables to not compromise their appearance. The papaya fruits covered with extract of neem fruits at $10 \%$ had a weight loss of $9.94 \%$, thus within this criterion. The positive effect of minimizing weight losses is the maintenance of a film on the fruit surface, which protects it against moisture loss. Neem extract also reduced the fresh weight loss in oranges after eight weeks of storage (AL-SAMARRAI; SINGH; SYARHABIL, 2013). On the other hand, Carnelossi et al. (2009) found increases in weight loss of papaya fruits when treated with essential oils of Eucalyptus citriodora L. and Cymbopogon citratus DC. Stapf (lemon grass).

The external quality of the fruit decreased throughout the storage period, with mean grade results at the end of the experiment of 1.83 (TC), 3.25 (T1), 2.50 (T2), 3.17 (T3) and 2.67 (T4) (Figure $1 \mathrm{~B})$. The fruits covered with extracts of neem leaves and fruits at 5\% (T1 and $\mathrm{T} 3$ ) presented the best external quality for the storage periods. According to Lima et al. (2012), the external appearance of Tommy-Atkisns mangoes was compromised by direct application of fennel extract, with grades below the accepted limit after 12 days of storage in BOD chamber at $10 \pm 5{ }^{\circ} \mathrm{C}$ and relative humidity of $88 \pm 2 \%$. The use of extracts on the fruit surface can promote a bright appearance, since some extracts contain essential oils; and form a protective barrier to the attack of microorganisms. On the other hand, the external fruit quality may reduce due to wilting caused by alterations in their physiological processes, leading to the wrinkle of the fruit due to weight and volume loss, depreciating its appearance and reducing its shelf life.

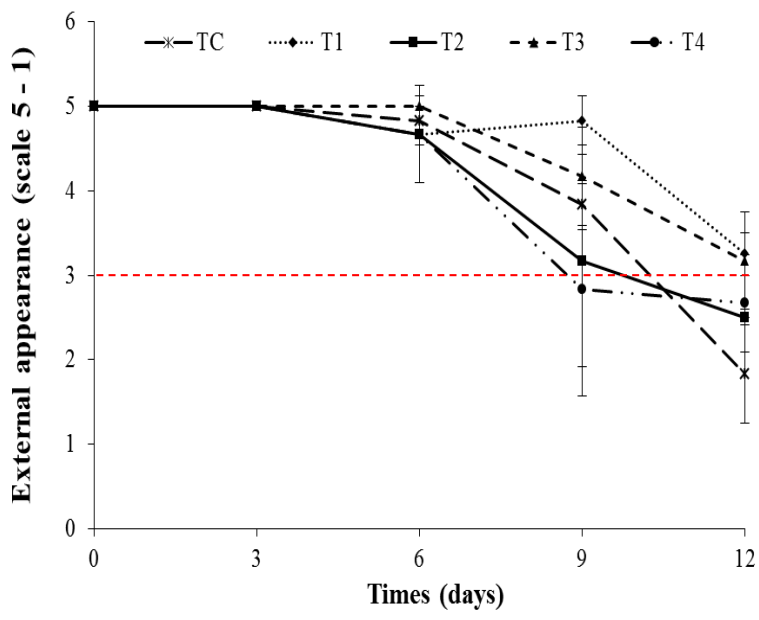

Figure 1. Fruit weight loss (A) and external appearance (B) of papaya Formosa Tainung-01 coated with extracts of neem leaves and fruits, stored at $30.4{ }^{\circ} \mathrm{C}$ and relative humidity of $42 \%$ for 12 days. $\mathrm{TC}=$ control, $\mathrm{T} 1=$ extract of the neem leaves at $5 \%, \mathrm{~T} 2=$ extract of the neem leaves at $10 \%, \mathrm{~T} 3=$ extract of neem fruits at $5 \%$ and $\mathrm{T} 4=$ extract of neem fruits at $10 \%$. 
The initial pulp firmness of the fruits was 105.37 N (Figure 2), which reduced especially from the $3^{\text {rd }}$ day of storage. At this day, fruits in $\mathrm{T} 2$ (extract of neem leaves at $10 \%$ ) had the lowest pulp firmness $(41.7 \mathrm{~N})$ compared with the control, which presented the highest pulp firmness. This result was probably because the extract affected the tissues of the fruits softening the fruit pulp. According to Lima et al. (2012), mangoes coated with fennel extracts $(1.5 \%)$ also have lower firmness than the control; and fruits coated with fennel $(1.5 \%)$ plus cassava starch $(3.0 \%)$ resulted in firmer fruits up to the $12^{\text {th }}$ (mangoes harvested with good agricultural practices) and $6^{\text {th }}$ day of storage (mangoes harvested without good agricultural practices). Martins et al. (2005) found similar results regarding the decrease of fruit pulp firmness during storage in papaya Golden applying extracts of fennel and hydrothermal treatments.

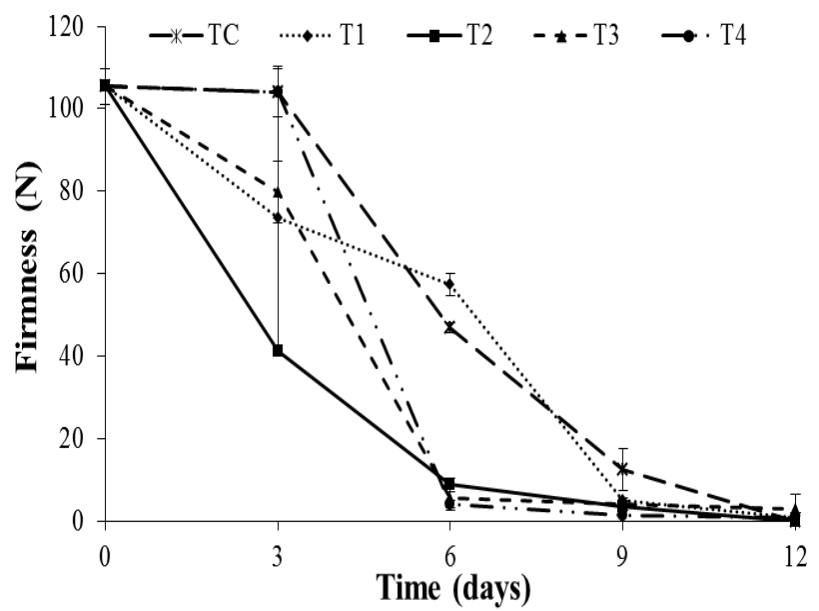

Figure 2. Fruit pulp firmness of papaya Formosa Tainung-01 coated with extracts of neem leaves and fruits, stored at $30.4{ }^{\circ} \mathrm{C}$ and relative humidity of $42 \%$ for 12 days. $\mathrm{TC}=$ control, $\mathrm{T} 1=$ extract of the neem leaves at $5 \%, \mathrm{~T} 2=$ extract of the neem leaves at $10 \%, \mathrm{~T} 3=$ extract of neem fruits at $5 \%$ and $\mathrm{T} 4=$ extract of neem fruits at $10 \%$.

The titratable acidity of the fruits evaluated had a small oscillation (Figure 3A), with the initial malic acid of $0.10 \%$ increasing in all treatments, especially from the $3^{\text {rd }}$ day of storage, with a subsequent decrease on the $9^{\text {th }}$ day of storage, since papaya is a fruit that does not present uniformity during the maturation process. According to Costa and Balbino (2002) this increase in pulp titratable acidity is probably due to the formation of galacturonic acid, as a consequence of pectin hydrolysis by the enzymes pectinametilesterase and polygalacturonase. The acidity increases with fruit ripening until $75 \%$ of yellow skin surface; Then, the acidity decreases, except inside the mesocarp, where titratable acidity increases until the fruit reaches full yellowing.

The fruits had a small increase in soluble solids contents throughout the storage period (Figure 3B). The soluble solids decrease in fruits in $\mathrm{T} 1$ and $\mathrm{T} 4$ by the $3^{\text {rd }}$ day of storage, presenting contents of 10.72 and $10.53^{\circ} \mathrm{Brix}$, respectively.

Fruits in T2 had the highest soluble solids content at the end of the storage period, probably due to their faster ripening, and loss of moisture, which were also responsible for their lower pulp firmness (Figure 2). The soluble solids found in the present study are higher than those found by Souza et al. (2014) for Papaya Formosa Tainung-01 coated with cassava starch. The highest concentration extract of neem leaves $(10 \%)$ may have accelerated some metabolic reactions that occur during maturation, since this is an organic compound. The soluble solids contents found are close to those found in papaya Formosa coated with an edible cassava starch-based coating (PEREIRA et al., 2006).

Growth of fungi occurred from the $6^{\text {th }}$ day of storage (Figure 4A). At this day, fruits in T2 had $0.83 \%$ of incidence, with later absence of fungi development. Fruits coated with the extracts presented reductions in the development of fungi compared with fruits in the control treatment, which presented $20.5 \%$ of incidence fungi at the end of the experiment. The fungi species with higher incidence in the evaluated samples were Alternaria sp., Aspergillus flavus, Aspergillus niger and Fusarium sp. (Figure 4B).

Lima et al. (2011) evaluated the efficiency of plant extracts in the control of nymphs of Bemisia tabaci biotype B and found that the use of neem oil was one of the most efficient. Oladimeji et al. (2013) evaluated the control of Fusarium verticilloides (Saccardo), with aqueous extracts of Azadirachta indica and Vernonia amygdalina, and found that both extracts can be used for preservation of tomato fruits, prolonging their shelf life. 

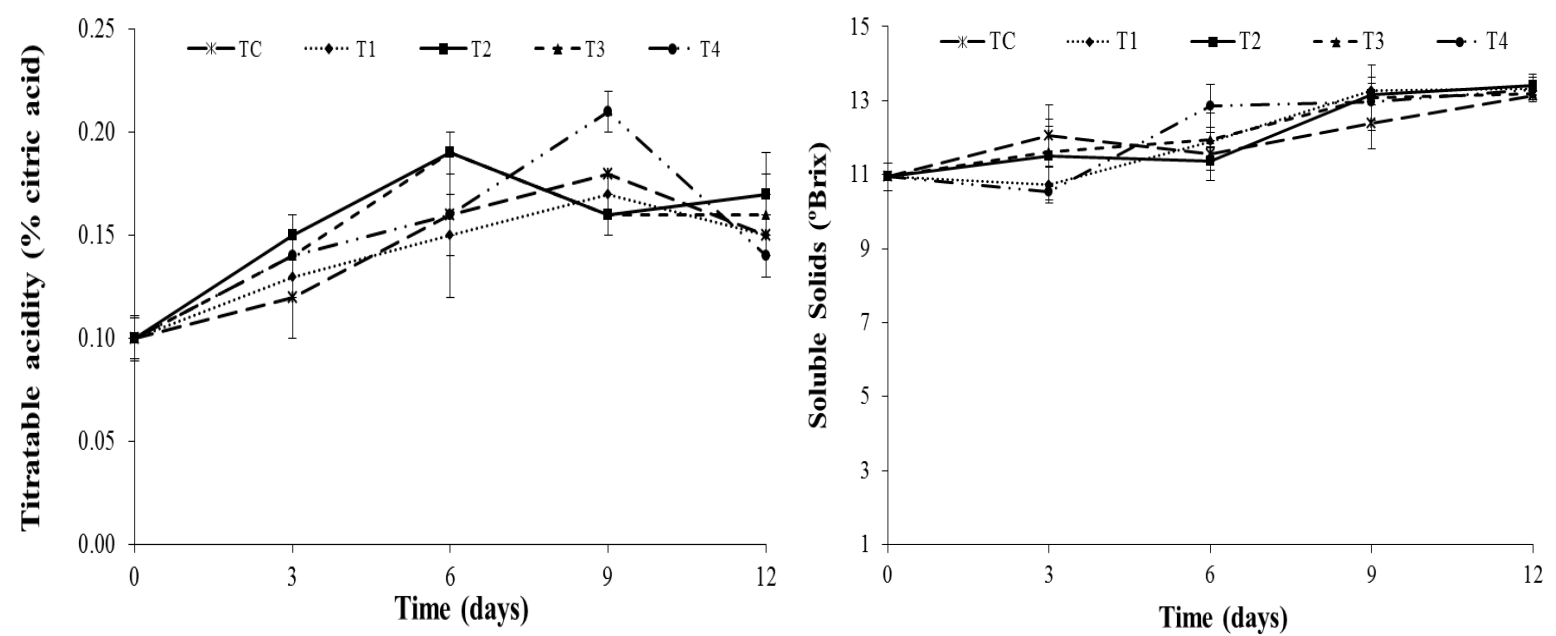

Figure 3. Titratable acidity (A) and soluble solids (B) of papaya Formosa Tainung-01 coated with extracts of neem leaves and fruits, stored at $30.4{ }^{\circ} \mathrm{C}$ and relative humidity of $42 \%$ for 12 days. TC $=$ control, $\mathrm{T} 1=$ extract of the neem leaves at $5 \%$, $\mathrm{T} 2=$ extract of the neem leaves at $10 \%, \mathrm{~T} 3=$ extract of neem fruits at $5 \%$ and $\mathrm{T} 4=$ extract of neem fruits at $10 \%$.
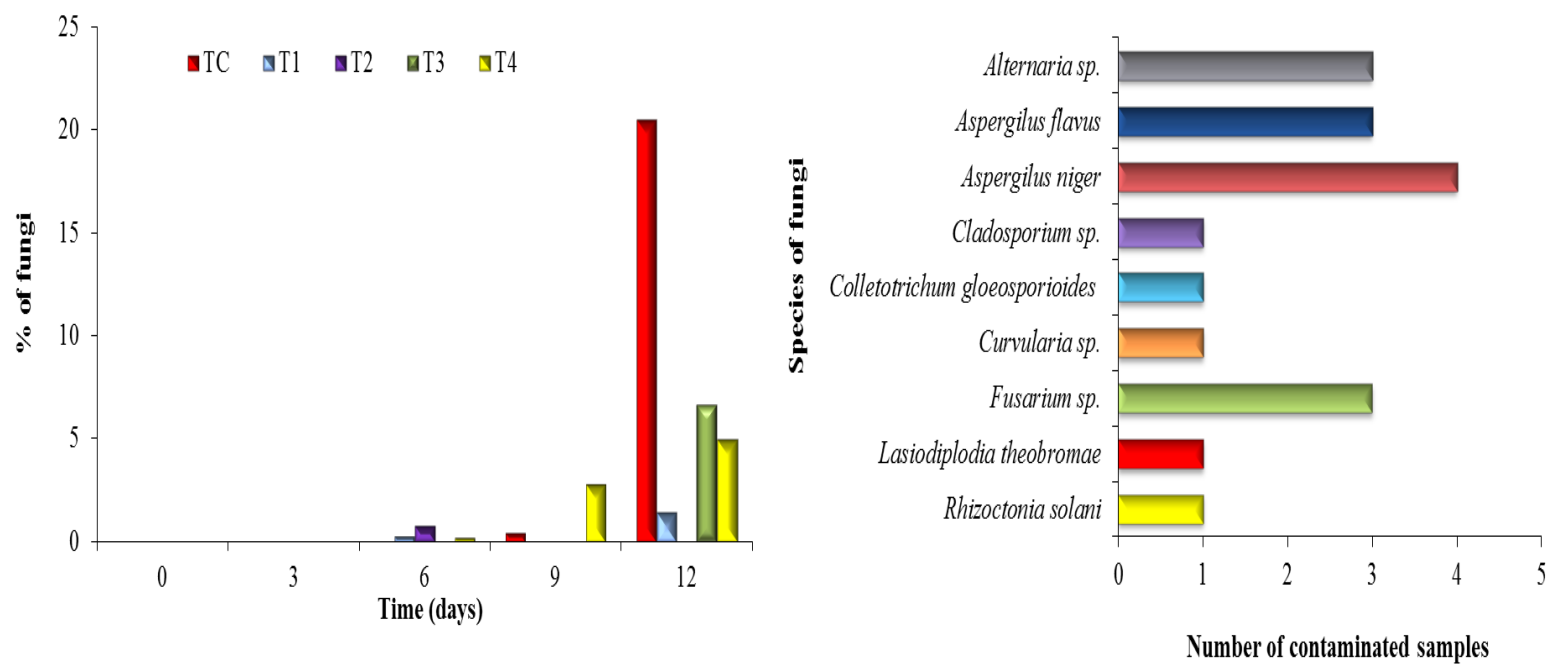

Figure 4. Percentage of fungi (A) and identification of fungus species (B) in papaya Formosa Tainung-01 coated with extracts of neem leaves and fruits, stored at $30.4{ }^{\circ} \mathrm{C}$ and relative humidity of $42 \%$ for 12 days. TC $=$ control, $\mathrm{T} 1=$ extract of the neem leaves at $5 \%, \mathrm{~T} 2=$ extract of the neem leaves at $10 \%, \mathrm{~T} 3=$ extract of neem fruits at $5 \%$ and $\mathrm{T} 4=$ extract of neem fruits at $10 \%$.

The growth of pathogens Monilinia fructicola, Penicillium expansum, Trichothecium roseum and Alternaria alternata in plum and pear fruits can also be reduced with the use of neem extracts (WANG et al., 2010). Tests involving extracts and residues of neem leaves showed inhibition of vegetative growth in many pathogens of the genus Fusarium ( $F$. oxysporum f. sp. ciceri (Fock.), F. oxysporum f. sp. Cepae (Hanzawa.), F. oxysporum (Snyder \& Hansen), F. solani Mart.) and from other fungi genera (Aspergillus, Sclerotinia, Pyricularia, Rhizoctonia, Penicillium). Some reports confirm the antifungal potential of this plant, denoting its efficiency in the control of diseases, especially those caused by fungi (MOSSINI; KEMMELMEIER, 2005). On the other hand, Venturoso et al. (2011) evaluated the antifungal activity of extracts on the development of phytopathogens and found that the extract of neem favored the growth of Fusarium solani, confirming the results found in the present work.

\section{CONCLUSIONS}

The use of extracts of neem leaves or fruits at $5 \%$ presented the best results on maintaining the external quality, and controlling the growth of phytopathogens in papaya fruits at post-harvest.

Based on the external appearance, papaya fruits treated with extracts of neem leaves or fruits at $5 \%$ had a shelf life of 12 days, while fruits treated with extracts of neem leaves and fruits at $10 \%$ had a shelf life of 9 days. The use of neem extracts reduced the development of fungi during the storage period compared with the control. The fungi species with 
the highest incidence in the samples evaluated were Alternaria sp., Aspergillus flavus, Aspergillus niger and Fusarium sp.

\section{REFERENCES}

AGNOLIN, C. A. et al. Eficácia do óleo de citronela [Cymbopogon nardus (L.) Rendle] no controle de ectoparasitas de bovinos. Revista Brasileira de Plantas Medicinais, Botucatu, v. 12, n. 4, p. 482487, 2010.

AL-SAMARRAI, G. F.; SINGH, H.; SYARHABIL, $M$. Extracts some plants on controlling green mold of orange and on postharvest quality parameters. World Applied Sciences Journal, Deira, v. 22, n. 4, p. 564$570,2013$.

AZEVEDO, L. A. S. Manual de quantificação de doenças de plantas. 1. ed. São Paulo, SP: Embrapa Ocidental, Embrapa Arroz e Feijão, Embrapa Hortaliças, 1998. 114 p.

BRITO, N. M. et al. Alternativas de controle de Chalara paradoxa na pós-colheita de abacaxi. Revista Caatinga, Mossoró, v. 24, n. 2, p. 52-58, 2011.

CARNELOSSI, P. R. et al. Óleos essenciais no controle pós-colheita de Colletotrichum gloeosporioides em mamão. Revista Brasileira de Plantas Medicinais, Botucatu, v. 11, n. 4, p. 399406, 2009.

ChITARRA, M. I. F.; ChITARRA, A. B. Póscolheita de frutos e hortaliças: fisiologia e manuseio. 2. ed. Lavras, MG: UFLA, 2005. 785 p.

COSTA, A. F. S.; BALBINO, J. M. S. Mamão: póscolheita. 1. ed. Cruz das Almas: Embrapa Mandioca Fruticultura, 2002. 59 p. (Frutas do Brasil, 21).

FERREIRA, E. F. et al. Uso de extratos vegetais no controle in vitro do Colletotrichum gloeosporioides Penz. coletado em frutos de mamoeiro (Carica papaya L.). Revista Brasileira de Fruticultura, Jaboticabal, v. 36, n. 2, p. 346-352, 2014.

INSTITUTO ADOLFO LUTZ - IAL. Normas analíticas, métodos químicos e físicos de alimentos. 4. ed. São Paulo, SP: Instituto Adolfo Lutz, 2008. 1020 p.

LEITE, C. D. et al. Controle Pós-Colheita da Podridão Amarga da Maçã com o Uso do Óleo de nim. Revista Brasileira de Agroecologia, Cruz Alta, v. 4, n. 2, p. 1644-1648, 2009.

LIBERATO, J. R.; TATAGIBA, J. S. Avaliação de fungicidas in vitro e em pós-colheita para o controle da antracnose e da podridão peduncular e frutos de mamão. Summa Phytopathologica, Botucatu, v. 27, n. 4, p. 409-414, 2001.

LIMA, A. B. et al. Conservação pós-colheita de manga 'Tommy Atkisns' orgânicas sob recobrimentos bio-orgânicos, Revista Brasileira de Fruticultura, Jaboticabal, v. 34, n. 3, p. 704-710, 2012.

LIMA, B. M. F. V. et al. Avaliação de extratos vegetais no controle de mosca branca em tomate. Revista Caatinga, Mossoró, v. 24, n. 4, p. 36-42, 2011.

LIMA, M. A. C. et al. Conservação de melões Gália 'Solar King' tratados com 1-metilciclopropeno. Horticultura Brasileira, Brasília, v. 22, n. 1, p. 121126,2004

MARTINS, L. P. et al. Controle de doenças na póscolheita de mamão Golden utilizando tratamento hidrotérmico e extrato de erva-doce. In: MARTINS, D. S. Papaya Brasil: mercado e inovações tecnológicas para o mamão. 1. ed. Vitória: INCAPER, 2005. v. 1, cap. 15, p. 422-426.

MOSSINI, S. A. G.; KEMMELMEIER, C. A árvore Nim (Azadirachta indica A. Juss): múltiplos usos. Acta Farmaceutica Bonaerense, Buenos Aires, v. 24, n. 1, p. 139-148, 2005.

NASCIMENTO, L. C.; NERY, A. R.; RODRIGUES, L. N. Controle de Colletotrichum gloeosporioides em mamoeiro, utilizando extratos vegetais, indutores de resistência e fungicida. Acta Scientiarum. Agronomy, Maringá, v. 30, n. 3, p. 313-319, 2008

OLADIMEJI, A. et al. Control of postharvest loss of tomato fruits caused by Fusarium verticilloides (Saccardo) Niremberg with aqueous leaf extracts of Azadirachta indica Juss and Vernonia amygdalina Del. International Journal of Phytofuels and Allied Sciences, Ilorin, v. 2, n. 1, p. 42-56, 2013.

PEREIRA, M. E. C. et al. Amadurecimento de mamão Formosa com revestimento comestível à base de fécula de mandioca. Ciência e Agrotecnologia, Lavras, v. 30, n. 6, p. 1116-1119, 2006.

QUINTELA, E. D.; PINHEIRO, P. V. Efeito de extratos botânicos sobre a oviposição de Bemisia tabaci biótipo B em feijoeiro. 1. ed. Santo Antônio de Goiás: Embrapa Arroz e Feijão, 2004. 6 p. (Comunicado Técnico, 92).

RIBEIRO, W. S. et al. Controle do fungo peduncular do abacaxi Pérola. Revista Brasileira de Produtos 
Agroindustriais, Campina Grande, v. 13, n. 1, p. 16,2011 .

SOUZA, A. F. et al. Fisiologia do amadurecimento de mamões de variedades comercializadas no Brasil. Revista Brasileira de Fruticultura, Jaboticabal, v. 36, n. 2, p. 318-328, 2014.

VENTUROSO, L. R. et al. Atividade antifúngica de extratos vegetais sobre o desenvolvimento de fitopatógenos. Summa Phytopathologica, Botucatu, v. 37 , n. 1, p. 18-23, 2011 .

WANG, J. et al. Antifungal activities of neem (Azadirachta indica) seed kernel extracts on postharvest diseases in fruits. African Journal of Microbiology Research, Nairobi, v. 4, n. 11, p. 1100-1104, 2010. 